\title{
Moringa water extract promising additive to prolong the activity of baculovirus under field-sunlight conditions in Egypt
}

\author{
A. El-Helaly ${ }^{*}$ (D) \\ ${ }^{\text {a} E n t o m o l o g y ~ a n d ~ P e s t i c i d e s ~ S c i e n c e ~ D e p a r t m e n t, ~ F a c u l t y ~ o f ~ A g r i c u l t u r e, ~ C a i r o ~ U n i v e r s i t y, ~}$ \\ Gamma Street, 12613, Giza, Egypt \\ *e-mail: alex.ahmad@yahoo.com
}

Received: June 21, 2019 - Accepted: July 30, 2019 - Distributed: November 30, 2020

(With 1 figure)

\begin{abstract}
Baculoviruses are considered as effective bio pesticides except of being not active under sunlight conditions. The aim of this study is to evaluate the capability of moringa extract to prolong virus activity under Egyptian field conditions especially that Moringa proved to be strong protective material under previous investigation under laboratory conditions the addition of moringa filters were tested on tomato plant foliage. Results are based on leaf bioassay using Spodoptera littoralis test insect and its nuclepolyhedrovirus (SpliNPV) as standard materials. The Original Activity Remaining (OAR) and Lethal Infectivity Time to $50 \%\left(\mathrm{LIT}_{50}\right)$ were estimated after exposure to natural sunlight. cacao and green tea were tested as comparative materials, which proved to be effective as virus protective agent in earlier investigations. The results showed that moringa additive at $10 \%$ sustained $50 \%$ of virus activity for 193.53 hours and 62.05 and 23.023 hours post application for cacao and green tea; respectively. While virus alone treatment lasts for only 17.551 hours. Moringa generally available, relatively cheap; it also has been tested and proved to be non-toxic, safe, and friendly to the environment. The obtained results showed the activity of moringa water extract in prolonging the virus activity under field application.
\end{abstract}

Keywords: antioxidants, baculovirus activity, field application, virus protection, moringa.

\section{Aditivo promissor do extrato aquoso de moringa para prolongar a atividade de baculovírus sob condições de campo-luz solar no Egito}

\section{Resumo}

Os baculovírus são considerados como biopesticidas eficazes, exceto por não estarem ativos sob condições de luz solar. O objetivo deste estudo é avaliar a capacidade do extrato de moringa para prolongar a atividade do vírus sob condições de campo egípcias, tendo em vista que Moringa provou ser um material protetor forte sob investigação anterior em condições de laboratório a adição de filtros moringa foram testados na folhagem de plantas de tomate. Os resultados são com base em bioensaios foliares utilizando o inseto-teste Spodoptera littoralis e seu vírus de poliedrose nuclear (VPNSl) como materiais padrões. A Atividade Original Restante (AOR) e o Tempo de Infectividade Letal até 50\% (LIT50) foram estimados após a exposição à luz solar natural. Cacau e chá verde foram testados como materiais comparativos, que se mostraram eficazes como agentes protetores do vírus em investigações anteriores. Os resultados mostraram que a moringa aditiva a 10\% sustentou 50\% da atividade viral por 193,53 horas e 62,05 e 23,023 horas após a aplicação de cacau e chá verde, respectivamente. Enquanto o tratamento sozinho do vírus dura apenas 17,551 horas, a moringa geralmente está disponível, e é relativamente barata; e a mesma também foi testada e provou ser não tóxica, segura e propícia ao meio ambiente. Os resultados obtidos mostraram a atividade do extrato aquosa da moringa no prolongamento da atividade do vírus sob aplicação em campo.

Palavras-chave: antioxidantes, atividade de baculovírus, aplicação em campo, proteção contra vírus, moringa.

\section{Introduction}

Several lepidopterous insects are important pests attacking agricultural crops In Egypt, Insect viruses, as biocontrol agents, may play an important role in pest control, thus reducing chemical insecticides. Baculoviruses especially NPV's are considered promising microbial agents for the biological control of lepidopterous pests Baculoviruses are safe and selective bio-insecticides, and used worldwide against many insect pests, especially lepidopterous (Singh et al., 2005). During the last 40 years several virus preparations have been developed and distributed. The effectiveness of viral products depends on many biological factors such as infectivity of the pathogen, the host insect behavior 
and the host plant species of the insect (Raymond et al., 2005). These viruses are proved safe due to their specificity. However, their use is hampered by their susceptibility to inactivation by ultraviolet (UV) in sun-light which is a major limitation for field application.

The long-term persistence of baculoviruses relies on their survival in the external environment in the form of occlusion bodies which provide a degree of protection from UV in sunlight. Many pathogens persist in reservoirs, i.e., microhabitats where survival is enhanced, due to protection from the degrading effects of UV irradiation (Krieg et al., 1981; Lasa et al., 2007).

The effect of sunlight and UV light particularly in the wavelength range of 280-320 $\mathrm{nm}$ (Chaudhari and Ramakrishman, 1988). Spodoptera littoralis nuclear polyhedrosis virus (SpliMNPV) was completely inactivated by exposure to short-wave ultraviolet radiation in the range $300-360 \mathrm{~nm}$ (Elnagar, 1983). On the other hand it was stated that wavelengths of $300-320 \mathrm{~nm}$ is responsible for almost all of the inactivation attributed to sunlight (Jones et al., 1993). Both virus concentration and radiation exposure time influenced the rate and degree of inactivation (Krieg et al., 1981; Shapiro and Domek, 2002).

Also, the plant foliage $\mathrm{pH}$ surface might have role in inactivation since the polyhedrosis virus is rapidly inactivated under field conditions on the upper leaf surface of tomato (Young and Yearian, 1974) loss in activity could observed during the initial dry-down of dew (Young and Yearian, 1974). On the other hand temperature and $\mathrm{pH}$ may have no effect on the sensitivity of PIB to ultraviolet radiation (Ignoffo and Garcia, 1990). The persistence of a nucleopolyhedrosis virus can be increased by the addition of certain dyes i.e., robin blue (Reddy and Divakar, 2001) Congo red (Baskaran et al., 1998; Shapiro, 1989) Indian ink (Krieg et al., 1980). Flourecent brightener (Martignoni and Iwai, 1985; Rabindra et al., 1989; Killick, 1990; Koa and Huang, 1992; Shapiro, 1992; Arivudainambi et al., 2000). Congo red (Baskaran et al., 1998). Different groups of chemicals such as shade formulation (Ignoffo and Garcia, 1996). Mixing petroleum spray oils (Mensah et al., 2005). Time of application (Alves et al., 2001). The role of the cationic nature of the berberine molecule and the importance of its absorbance spectrum in (Cohen et al., 2001). Also starch-encapsulated (Ignoffo et al., 1991). The addition of extracts ofinstar (Shapiro, 1984). Dar-mol molasses, Shade and Coax (Shapiro et al., 1983). charcoal, yeast extract, brewers' yeast (Jaques, 1971). Although previous studies proved certain protective effects of some material information about the efficiency in field application and the economical point of view are lacking.

All previous materials found to be expensive or difficult to apply in filed that lead scientists all over the world to use natural derived antioxidants, the addition of a caffeinated green tea (Shapiro et al., 2008). An extract of mango leaves (Muralibaskaran et al., 2000) the potentials of vitamins folic acid, pyridoxine, and riboflavin (Ramakrishnan and Chaudhary, 1991) diludin and ionol (Zarin and Eglite, 1985) pantothenic acid, pyridoxine, folic acid and riboflavin protected the virus. Pantothenic acid and pyridoxine (Shapiro, 1985).

Folic acid, riboflavine, pyridoxine, eucalyptus (Deotale et al., 2003). Nano zinc oxide and nano aluminum oxides (El-Helaly and Sayed, 2015) mixing with syenergestic effect like spinosa (El-Helaly and El-bendary, 2013) different natural derived plant antioxidants (El-Helaly et al., 2009, 2013) mixing different natural antioxidants (El-Helaly, 2016) this investigation was to complete my promising laboratory results investigations moringa and rice bran in laboratory conditions (El-Helaly, 2013) which proved that moringa promising additive worth to be evaluated under field conditions.

\section{Material and Methods}

\subsection{Test insect}

The test insect used in the present investigation is the Egyptian cotton leaf worm, Spodoptera littoralis. It was established on the semi-synthetic diet described by Shorey and Hale (1965) with the exclusion of formaldehyde from diet ingredients and replacing the methyl p- hydroxyl benzoate with sodium- benzoate.

\subsection{Virus inocula}

Spodoptera littoralis multiple embedded nucleopolyhedrovirus, Egyptian isolate (SpliMNPV) was the test virus used in the investigation.

\subsection{Additives}

Moringa, cacao and green tea plant-derived materials were evaluated as UV-protective additives to SpliMNPV suspension. Five or ten gram of each dry plant material was soaked in $100 \mathrm{~mL}$ distilled water for 24 hours then blended and filtrated through three layers of muslin and. The filtrate was the stock additive to the tested virus concentration (1x $10^{9} \mathrm{PIB}$ 's/ $\mathrm{mL}$ ) to prepare a final concentration of 5 or $10 \%$ of the material additive according to the method described by Shapiro et al. (2008).

\subsection{Field experiment}

An area under tomato plants about $1 / 4$ feddan ( 1 feddan $=4200 \mathrm{~m}^{2}$ ) was used and one small scale field test was set up to confirm laboratory results (El-Helaly, 2013). Two different concentrations of tested additives were prepared ( 5 and 10\% w/v) $12 \mathrm{hr}$. before spraying and kept in the fridge ready to use. The virus inocula SpliNPV was diluted in distilled de-ionized water and the suspension was adjusted to $10^{8} \mathrm{OBs} / \mathrm{mL}$ (=LC 90-95). At the time of field application, the virus and tested additives were thoroughly mixed together and the measured volume was transferred into a hand sprayer. The sticker arabic gum $(0.25 \%)$ was added to each NPV dilute as a sticking agent. Virus suspension treatments were applied separately to tomato foliage using one litre hand sprayer. Untreated leaves and virus treated leaves were randomly collected at $0,1,2,4,7$, and 10 days post application and kept individually in plastic bags at room temperature until tested. Each leaf was placed into a glass bottle, on which 10 neonate larvae were allowed 
to feed for $48 \mathrm{hr}$. before transferred daily to fresh leaves from the same treatment. Larval mortality was recorded at day $0,1,2,4,7,10$ days thereafter until day 14 . Virus persistence was calculated as \% OAR (percentage of Original Activity Remaining) based upon $100 \%$ mortality at ' 0 ' day post treatment, Potency was calculated for each treatment. Bioassay tests were repeated in five replicates with 10 larvae per treatment (Shapiro et al., 2008). The hydrogen ion concentration $(\mathrm{pH})$ values of all tested natural additive products were measured at $1 \%$ concentration using Beckman zeromatic SS-3 pH meter (Beckman instrument, Fullerton, and CA) . The absorption of $1 \%$ concentration of the 3 tested plant-derived materials was measured using Spectrophotometer (Lambda EZ201).

\subsection{Statistical analysis}

Concentration-mortality regressions were calculated to determine the effectiveness of tested material as UV protective additives for the SpliMNPV. Slope and $\mathrm{LC}_{50 \mathrm{~s}}$ values were calculated according to the method described by Finney (1971). Original activity remaining percentages (OARs \%) were determined for each treatment according to Muro and Paul (1985) in which NPV- caused larval mortality post UV exposure were divided by NPV- caused larval mortality pre UV exposure and multiplied by 100 .

\section{Results and Discussion}

This experiment was designed to compare and confirm the protective potency of moringa when used with virus sprayed on tomato foliage in the field under the natural conditions of UV in sunlight. In the case of using SpliNPV alone treatment, the recorded rates of mortality among $S$. littoralis neonate larvae after exposure periods of $10,24,48,96$ and168 hours to natural conditions were $76.00,42.00,2.08,0.00$ and $0.00 \%$, respectively, (the calculated LIT50 was only 17.55 hours) (Table 1 ). In the case of moringa additive at $5 \%$, the rates of mortality were $96.00,94.00,86.00,44.00$ and 34.00 respectively, (the calculated LIT50 was 120.915 hours). With cacao additive at $5 \%$, the rates of mortality were $100.00,84.00,60.41,28.00$ and $6.00 \%$ (the calculated LIT50 was 48.266 hours). With green tea $5 \%$ additive, rates of mortality were $76.00,68.00,42.00$, 14.00 and $4.00 \%$, respectively, (the LIT50 was only 23.47 hours). In the case of moringa additive at $10 \%$, the rates of mortality were $100.00,96.00,88.00,64.00$ and $54.00 \%$, respectively, (the calculated LIT50 was 193.53 hours). For cacao at $10 \%$ additive; the rates of mortality were $97.77,89.79,68.08,38.00$ and $12.00 \%$ (LIT50 reached 62.05 hours). With green tea $10 \%$ additive the rates of mortality were $78.26,67.34,46.44,22.44$ and $2.08 \%$, respectively, (the LIT50 was 23.02 hours). As the data shows that moringa $10 \%$ additive increased the persistence of $50 \%$ of its activity for almost eight days (193.53 hours 8.063 days), compared to ( 62.05 hours $=2.58$ days $)$ and ( 23.47 hours $=0.977$ days $)$ for cacao and green tea, respectively. (Table 1) the lower concentration 5\% also moringa gave the best protection of persistence of $50 \%$ of its activity for almost five days ( 120.915 hours $=5.033$ days $)$ compared with ( 48.266 hours $=2.011$ days $)$ and $(23.47$ hours $=0.959$ days $)$ for cacao and green tea, respectively (Figure 1), while virus

Table 1. Effect of moringa, cacao and green tea additives at both 5 and $10 \%$ concentrations on the persistence of Spodoptera littoralis NPV sprayed on tomato foliage and bioassay against cotton leaf worm neonate larvae.

\begin{tabular}{|c|c|c|c|c|c|c|c|}
\hline \multirow{3}{*}{$\begin{array}{c}\text { Irradiation } \\
\text { periods } \\
\text { (hrs.) }\end{array}$} & \multirow{3}{*}{$\begin{array}{c}\text { Mortality } \\
\% \text { due to } \\
\text { SpLiNPV } \\
\text { alone }\end{array}$} & \multicolumn{6}{|c|}{ Mortality \% due to $S p L i$ NPV alone+ } \\
\hline & & \multicolumn{2}{|c|}{ moringa } & \multicolumn{2}{|c|}{ cacao } & \multicolumn{2}{|c|}{ Green tea } \\
\hline & & $5 \%$ & $10 \%$ & $5 \%$ & $10 \%$ & $5 \%$ & $10 \%$ \\
\hline Zero time & $\begin{array}{l}100.00 \\
(50 / 50)\end{array}$ & $\begin{array}{l}100.00 \\
(49 / 49)\end{array}$ & $\begin{array}{l}100.00 \\
(50 / 50)\end{array}$ & $\begin{array}{c}88.00 \\
(44 / 50)\end{array}$ & $\begin{array}{c}98.00 \\
(49 / 50)\end{array}$ & $\begin{array}{c}97.95 \\
(48 / 49)\end{array}$ & $\begin{array}{l}100.00 \\
(47 / 47)\end{array}$ \\
\hline 10 & $\begin{array}{c}76.00 \\
(38 / 50)\end{array}$ & $\begin{array}{c}96.00 \\
(48 / 50)\end{array}$ & $\begin{array}{l}100.00 \\
(50 / 50)\end{array}$ & $\begin{array}{l}100.00 \\
(47 / 47)\end{array}$ & $\begin{array}{c}97.77 \\
(44 / 45)\end{array}$ & $\begin{array}{c}76.00 \\
(38 / 50)\end{array}$ & $\begin{array}{c}78.26 \\
(36 / 46)\end{array}$ \\
\hline 24 & $\begin{array}{l}42.00 \\
(21 / 50)\end{array}$ & $\begin{array}{l}94.00 \\
(47 / 50)\end{array}$ & $\begin{array}{l}96.00 \\
(48 / 50)\end{array}$ & $\begin{array}{l}84.00 \\
(42 / 50)\end{array}$ & $\begin{array}{c}89.79 \\
(44 / 49)\end{array}$ & $\begin{array}{l}68.08 \\
(32 / 47)\end{array}$ & $\begin{array}{c}67.34 \\
(33 / 49)\end{array}$ \\
\hline 48 & $\begin{array}{c}2.08 \\
(1 / 48)\end{array}$ & $\begin{array}{c}86.00 \\
(43 / 50)\end{array}$ & $\begin{array}{c}88.00 \\
(44 / 50)\end{array}$ & $\begin{array}{c}60.41 \\
(29 / 48)\end{array}$ & $\begin{array}{l}68.08 \\
(32 / 47)\end{array}$ & $\begin{array}{c}42.00 \\
(21 / 50)\end{array}$ & $\begin{array}{c}46.93 \\
(23 / 49)\end{array}$ \\
\hline 96 & $\begin{array}{c}0.00 \\
(0 / 50)\end{array}$ & $\begin{array}{l}44.00 \\
(22 / 50)\end{array}$ & $\begin{array}{l}64.00 \\
(32 / 50)\end{array}$ & $\begin{array}{l}28.00 \\
(14 / 50)\end{array}$ & $\begin{array}{c}38.00 \\
(19 / 50)\end{array}$ & $\begin{array}{l}14.00 \\
(7 / 50)\end{array}$ & $\begin{array}{c}22.44 \\
(11 / 49)\end{array}$ \\
\hline 168 & $\begin{array}{c}0.00 \\
(0 / 50)\end{array}$ & $\begin{array}{c}34.00 \\
(17 / 50)\end{array}$ & $\begin{array}{l}54.00 \\
(27 / 50)\end{array}$ & $\begin{array}{c}6.00 \\
(3 / 50)\end{array}$ & $\begin{array}{l}12.00 \\
(6 / 50)\end{array}$ & $\begin{array}{c}4.00 \\
(2 / 50)\end{array}$ & $\begin{array}{c}2.08 \\
(1 / 48)\end{array}$ \\
\hline Control* & $\begin{array}{c}0.00 \\
(0 / 50)^{* *}\end{array}$ & $\begin{array}{c}0.00 \\
(0 / 50)\end{array}$ & $\begin{array}{c}0.00 \\
(0 / 48)\end{array}$ & $\begin{array}{c}0.00 \\
(0 / 49)\end{array}$ & $\begin{array}{c}0.00 \\
(0 / 47)\end{array}$ & $\begin{array}{c}0.00 \\
(0 / 48)\end{array}$ & $\begin{array}{c}0.00 \\
(0 / 49)\end{array}$ \\
\hline LIT50 hrs. & 17.551 & 120.915 & 193.5309 & 48.266 & 62.0532 & 23.4762 & 23.023 \\
\hline Slope +/- & 0.4822 & 0.2976 & 0.3009 & 0.1240 & 0.2220 & 0.1770 & 0.1409 \\
\hline Potency(Fold) & ---------- & 6.889 & 11.026 & 2.747 & 3.535 & 1.3375 & 1.311 \\
\hline
\end{tabular}




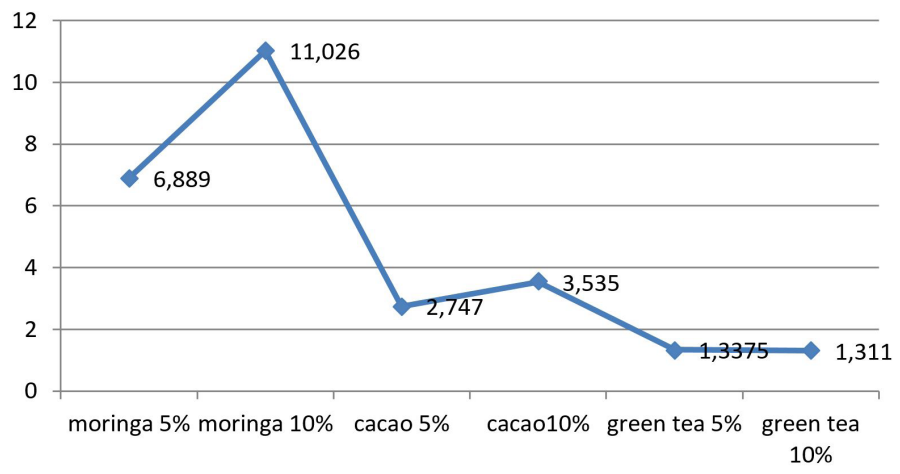

Figure 1. Effect of moringa, cacao and green tea additives at both 5 and $10 \%$ concentrations on Potency (Fold) of Spodoptera littoralis NPV sprayed on tomato foliage and bioassay against cotton leaf worm neonate larvae.

Table 2. Effect of Moringa, cacao and green tea additives at both 5 and $10 \%$ concentrations on Original Activity Remaining (OAR) of Spodoptera littoralis NPV sprayed on tomato foliage and bioassay against cotton leaf worm neonate larvae.

\begin{tabular}{|c|c|c|c|c|c|c|c|}
\hline \multirow{3}{*}{$\begin{array}{c}\text { Irradiation } \\
\text { periods } \\
\text { (hrs.) } \\
\text { concentrations }\end{array}$} & \multirow{3}{*}{$\begin{array}{c}\text { Mortality } \\
\text { \% due to } \\
\text { SpLiNPV } \\
\text { alone } \\
-----------\end{array}$} & \multicolumn{6}{|c|}{ Mortality $\%$ due to $S p L i N P V$ alone+ } \\
\hline & & \multicolumn{2}{|c|}{ moringa } & \multicolumn{2}{|c|}{ cacao } & \multicolumn{2}{|c|}{ Green tea } \\
\hline & & $5 \%$ & $10 \%$ & $5 \%$ & $10 \%$ & $5 \%$ & $10 \%$ \\
\hline Zero time & 100.00 & 100.00 & 100.00 & 88.00 & 98.00 & 97.95 & 100.00 \\
\hline 10 & 76.00 & 96.00 & 100.00 & 100.00 & 99.76 & 77.59 & 78.26 \\
\hline 24 & 42.00 & 94.00 & 96.00 & 95.45 & 91.62 & 69.50 & 67.34 \\
\hline 48 & 2.08 & 86.00 & 88.00 & 68.64 & 69.46 & 42.87 & 46.93 \\
\hline 96 & 0.00 & 44.00 & 64.00 & 31.81 & 38.77 & 14.29 & 22.44 \\
\hline 168 & 0.00 & 34.00 & 54.00 & 6.81 & 12.24 & 4.08 & 2.08 \\
\hline Control* & 0.00 & 0.00 & 0.00 & 0.00 & 0.00 & 0.00 & 0.00 \\
\hline
\end{tabular}

*Refers to either distilled water or additives alone at $5 \%$ or $10 \%$.

treatment alone gave only (17.551 hours $=0.7312$ day). Folds of protection (Figure 1 and Table 1) in comparison to virus alone (17.551 hours), it was found that both moringa concentrations were superior where it gave 6.889 folds and 11.026 folds for $5 \%$ and $10 \%$; Respectively followed by $2.747,3.535,1.337$ and 1.311 folds for cacao $\% \%$, cacao $10 \%$, green tea $5 \%$ and green tea $10 \%$; Respectively. It is also worth to be mentioned that from these data could concluded that both moringa and cacao were more effective when their concentrations increased vice versa green tea gave stable low protection even when its concentration was increased. OAR was also calculated (Table 2) and it reveal the same previous trend of protection where moringa $10 \%$ was the best candidate with $54.00 \%$ OAR ' 168 days post application followed by $34.00,12.24,6.81,4.08$ and 2.08 OAR $\%$ for moringa $5 \%$, cacao $10 \%$, cacao $5 \%$, green tea $10 \%$ and green tea $5 \%$; Respectively. When these results compared with my laboratory experiments at previous investigation (El-Helaly, 2013) it was evident that moringa was best protective additive compared to other antioxidants in the enhancement of SpliMNPV activities under the suppressive effect of UV. Testing the polarity of hydrogen ion at the tested concentration $(5 \%$ or $10 \%)$ revealed no apparent role to the $\mathrm{pH}$ ion in relation to viral activity as well as counting the polyhedra in mixture of virus + additive. The most effective additive moringa had a pH degree 6.90 followed by 6.85 and 7.1 for cacao and green tea respectively (almost neutral). Also, Argauer and Shapiro (1997) in this respect found no correlation between $\mathrm{pH}$ and activity enhancement.

The mode of action of UV-protective additives is measured by its efficiency in absorbance of the ultraviolet light; UV-B region, 280-320 nm, UV-A region, 320-400 nm or both of them (Shapiro, 1989). The success of additive substances was thought to be due to its good absorption in the ultraviolet UV-B as well as UV-A (Shapiro, 1985).

In the present study, the obtained results revealed that all tested additives without significant differences showed a high rate of absorption (from 210-400 nm) especially in UV region of the inactivation $300-320 \mathrm{~nm}$ at the $1 \%$ concentration (it was undoable to test higher concentrations). In conclusion, there was no correlation between absorption at the UV destructive range and the additive material responsible for protection of virus; this could be referred to using crude materials containing huge complexes of chemical compounds. 
Finally, moringa found to be the best additives with a marginal difference from the second best candidate (cacao). I recommend to add moringa at $10 \%$ concentration for all virus treatment in field and for industrial it should be added for commercial formulation as far. Future studies should be done in order to evaluate the stability of adding antioxidants in formulation under different degrees of temperature and humidity toward getting new stable viral formulation under Egyptian sunny conditions.

\section{Acknowledgements}

I would like to acknowledge Prof Dr Salah Elnagar and Dr Mohammed Abdelkader El-Sheikh (Department of Entomology and Pesticides science) for revising manuscript.

\section{References}

ALVES, L.F.A., BATISTA, F.A. and AUGUSTO, B.N.T., 2001. Photoprotection of nuclear polyhedrosis virus under field and laboratory conditions. Manejo Integrado de Plagas, vol. 62 , pp. 60-64.

ARGAUER, R. and SHAPIRO, M., 1997. Fluorescence and relative activities of stilbene optical brighteners as enhancers for the gypsy moth (Lepidoptera: Lymantriidae) baculovirus. Journal of Economic Entomology, vol. 90, no. 2, pp. 416-420. http://dx.doi.org/10.1093/jee/90.2.416.

ARIVUDAINAMBI, S., SELVANARAYANAN, V. and VIKASH, A., 2000. Enhancing the efficacy and persistency of Spodoptera litura (Fab.) nuclear polyhedrosis virus using UV irradiation protectants. Indian Journal of Experimental Biology, vol. 38, no. 11, pp. 1175-1176. PMid:11395967.

BASKARAN, R.K.M., VENUGOPAL, M.S. and MAHADEVAN, N.R., 1998. Optical brighteners as UV protectants and their influence on the virulence of nuclear polyhedrosis virus of Spodoptera litura (Fabricius) (Lepidoptera: noctuidae). Journal of Biological Control, vol. 11, no. 12, pp. 17-22.

CHAUDHARI, S. and RAMAKRISHMAN, N., 1988. Effect of temperature, sunlight and UV-rays on the infectivity of nuclear polyhedrosis virus of Bihar hairy caterpillar, Spilosoma obliqua (Walker). Journal of Entomological Research, vol. 12, no. 2, pp. 109-112.

COHEN, E., JOSEPH, T. and WASSERMANN-GOLAN, M., 2001. Photostabilization of biocontrol agents by berberine. International Journal of Pest Management, vol. 47, no. 1, pp. 63-67. http://dx.doi.org/10.1080/09670870150215612.

DEOTALE, R.O., DAWANE, P.N., UNDIRWADE, D.B., DESHMUKH, I.B. and BISANE, K.D., 2003. Performance of UV protectants for the effectiveness of HaNPV against Helicoverpa armigera on chickpea. Journal of Soils and Crops, vol. 13, no. 1, pp. 154-157.

EL-HELALY, A. and EL-BENDARY, H., 2013. Impact of spinosad and nucleopolyhedrovirus alone and incombination against the cotton leaf worm Spodoptera littoralis under laboratory. Applied Scientific Research, vol. 2, no. 1, pp. 17-21.

EL-HELALY, A. and SAYED, W., 2015. New approach based on nanotechnology in baculovirus protection. Egyptian Academic Journal of Biology and Science., vol. 7, no. 1, pp. 163-175. http:// dx.doi.org/10.21608/eajbsf.2015.17251.
EL-HELALY, A., 2013. Additives for a baculovirus against ultraviolet effect. Applied Scientific Research, vol. 4, no. 1, pp. 187-191.

EL-HELALY, A., 2016. Mixture of natural antioxidants can improve Spodoptera littoralis (Bosid.) nucleopolyhedrovirus, (Baculoviridae) stability under Egyptian field conditions. Journal of Plant Protection and Pathology, vol. 7, no. 8, pp. 533-539. http://dx.doi.org/10.21608/jppp.2016.51209.

EL-HELALY, A., KHATTAB, M., SALAMOUNY, S., ELSHEIKH, M. and ELNAGAR, S., 2009. Preliminary evaluation of natural antioxidants as uv- protectants of Spodoptera littoralis nucleopolyhedrovirus (Baculoviridae). In: Proceedings of the 4th Conference on Recent Technologies in Agriculture "Challenge of Agriculture Moderization", 2009, Cairo. Cairo: Faculty of Agriculture, Cairo University, pp. 7-13.

EL-HELALY, A., KHATTAB, M., SALAMOUNY, S., ELSHEIKH, M. and ELNAGAR, S., 2013. Promising additives to protect the activity of baculovirus biocontrol agent under field- sunlight conditions in Egypt. Journal of Life Science, vol. 7 , no. 5, pp. 495-500.

ELNAGAR, S., 1983. The inactivation of nuclear polyhedrosis virus by ultraviolet radiation. Bulletin of the Entomological Society of Egypt: Economic Series, vol. 13, pp. 171-174.

FINNEY, D.J., 1971. Probit analysis. 3rd ed. Cambridge: Cambridge University.

IGNOFFO, C.M. and GARCIA, C., 1990. Influence of physical factors (water, $\mathrm{pH}$, temperature) on simulated sunlight-UV inactivation of occluded HzSNPV. In: Proceedings of the $V$ International Colloquium on Invertebrate Pathology and Microbial Control, 1990, Adelaide, Australia. Australia.

IGNOFFO, C.M. and GARCIA, C., 1996. Simulated sunlight UV sensitivity of experimental dust formulations of the nuclear polyhedrosis virus of Helicoverpa/Heliothis. Journal of Invertebrate Pathology, vol. 67, no. 2, pp. 192-194. http://dx.doi.org/10.1006/ jipa.1996.0031.

IGNOFFO, C.M., SHASHA, B.S. and SHAPIRO, M., 1991. Sunlight ultraviolet protection of the Heliothis nuclear polyhedrosis virus through starch encapsulation technology. Journal of Invertebrate Pathology, vol. 57, no. 1, pp. 134-136. http://dx.doi. org/10.1016/0022-2011(91)90053-S.

JAQUES, R.P., 1971. Tests on protectants for foliar deposits of a polyhedrosis virus. Journal of Invertebrate Pathology, vol. 17, no. 1, pp. 9-16. http://dx.doi.org/10.1016/0022-2011(71)90119-4.

JONES, K.A., MOAWAD, G., MCKINLEY, D.J. and GRZYWACZ, D., 1993. The effect of natural sunlight on Spodoptera littoralis nuclear polyhedrosis virus. Biocontrol Science and Technology, vol. 3, no. 2, pp. 189-197. http://dx.doi. org/10.1080/09583159309355275.

KILLICK, H.J., 1990. Influence of droplet size, solar ultraviolet light and protectants, and other factors on the efficacy of baculovirus sprays against Panolis flammea (Schiff.) (Lepidoptera; Noctuidae). Crop Protection, vol. 9, no. 1, pp. 21-28. http://dx.doi. org/10.1016/0261-2194(90)90041-5.

KOA, S.S. and HUANG, L.H., 1992. Effectiveness of UV protectants for Spodoptera exigua (Hubner) nuclear polyhedrosis virus. Chinese Journal of Entomology, vol. 12, no. 1, pp. 31-40.

KRIEG, A., GRONER, A., HUBER, J. and MATTER, M., 1980. The effect of medium- and long-wave ultraviolet rays (UV-B and UV-A) on insect-pathogenic bacteria and viruses and their 
influence by UV-protectants. Nachrichtenblatt des Deutschen Pflanzenschutzdienstes., vol. 32, no. 7, pp. 100-106.

KRIEG, A., GRONER, A., HUBER, J. and ZIMMERMANN, G., 1981. Inactivation of various insect pathogens by ultraviolet rays. Zeitschrift fur Pflanzenkrankheiten und Pflanzenschutz, vol. 88 , no. 1 , pp. $38-48$.

LASA, R., RUIZ-PORTERO, C., ALCAZAR, M.D., BELDA, J.E., CABALLERO, P. and WILLIAMS, T., 2007. Efficacy of optical brightener formulations of Spodoptera exigua multiple nucleopolyhedrovirus (SeMNPV) as a biological insecticide in greenhouses in southern Spain. Biological Control, vol. 40, no. 1, pp. 89-96. http://dx.doi.org/10.1016/j.biocontrol.2006.06.015.

MARTIGNONI, M.E. and IWAI, P.J., 1985. Laboratory evaluation of new ultraviolet absorbers for protection of Douglas fir tussock moth (Lepidoptera: Lymantriidae) Baculovirus. Journal of Economic Entomology, vol. 78, no. 4, pp. 982-987. http://dx.doi. org/10.1093/jee/78.4.982.

SHAPIRO, M. and DOMEK, J., 2002. Relative effects of ultraviolet and visible light on the activities of corn earworm and beet armyworm (Lepidoptera: Noctuidae) nucleopolyhedroviruses. Journal of Economic Entomology, vol. 95, no. 2, pp. 261-268. http://dx.doi.org/10.1603/0022-0493-95.2.261. PMid:12019999.

MENSAH, R.K., LIANG, W., GIBB, D., COATES, R. and JOHNSON, D., 2005. Improving the efficacy of nuclear polyhedrosis virus and Bacillus thuringiensis against Helicoverpa spp. with ultra violet light protected petroleum spray oils on cotton crops in Australia. International Journal of Pest Management, vol. 51, no. 2, pp. 101-109. http://dx.doi.org/10.1080/09670870400028334.

MURALIBASKARAN, R.K., VENUGOPAL, M.S. and MAHADEVAN, N.R., 2000. Potential of vitamins as ultraviolet screens for Spodoptera litura (Lepidoptera: Noctuidae) nuclear polyhedrosis virus. Indian Journal of Agricultural Sciences, vol. 70, no. 4, pp. 264-266.

MURO, E.M. and PAUL, J.I., 1985. Laboratory evaluation of new ultraviolet absorbers for protection of Douglas-fir tussock moth (Lepidoptera: Lymantriidae) baculovirus. Journal of Economic Entomology, vol. 78, pp. 951-957.

RABINDRA, R.J., SATHIAH, N., MUTHAIAH, C. and JAYARAJ, S., 1989. Controlled droplet application of nuclear polyhedrosis virus with adjuvants and UV protectants for the control of Heliothis armigera Hbn. on chickpea. Journal of Biological Control, vol. 3, no. 1, pp. 37-39.

RAMAKRISHNAN, N. and CHAUDHARY, S., 1991. Effectiveness of some ultra violet light protectants on the activity of nuclear polyhedrosis virus of Spodoptera litura (Fabricius). Indian Journal of Entomology, vol. 53, no. 4, pp. 548-551.

RAYMOND, B., HARTLEY, S.E., CORY, J.S. and HAILS, R.S., 2005. The role of food plant and pathogen-induced behaviour in the persistence of a nucleopolyhedrovirus. Journal of Invertebrate
Pathology, vol. 88, no. 1, pp. 49-57. http://dx.doi.org/10.1016/j. jip.2004.09.005. PMid:15707869.

REDDY, A.R. and DIVAKAR, B.J. 2001. Effect of Robin blue on the efficacy of nuclear polyhedrosis virus for the management of Helicoverpa armigera (Hub.) in groundnut crop. In: Proceedings of the National Symposium: Perspectives in Biotechnology, 2001, Warangal, India. India, pp. 41-43.

SHAPIRO, M., 1984. Host tissues and metabolic products as ultraviolet screens for the gypsy moth (Lepidoptera: Lymantriidae) nucleopolyhedrosis virus. Environmental Entomology, vol. 13, no. 4, pp. 1131-1134. http://dx.doi.org/10.1093/ee/13.4.1131.

SHAPIRO, M., 1985. Effectiveness of B vitamins as UV screens for the gypsy moth (Lepidoptera: Lymantriidae) nucleopolyhedrosis virus. Environmental Entomology, vol. 14, no. 6, pp. 705-708. http://dx.doi.org/10.1093/ee/14.6.705.

SHAPIRO, M., 1989. Congo red as an ultraviolet protectant for the gypsy moth (Lepidoptera: Lymantriidae) nuclear polyhedrosis virus. Journal of Economic Entomology, vol. 82, no. 2, pp. 548555. http://dx.doi.org/10.1093/jee/82.2.548.

SHAPIRO, M., 1992. Use of optical brighteners as radiation protectants for gypsy moth (Lepidoptera: Lymantriidae) nuclear polyhedrosis virus. Journal of Economic Entomology, vol. 85, no. 5, pp. 1682-1686. http://dx.doi.org/10.1093/jee/85.5.1682.

SHAPIRO, M., AGIN, P.P. and BELL, R.A., 1983. Ultraviolet protectants of the gypsy moth (Lepidoptera: Lymantriidae) nucleopolyhedrosis virus. Environmental Entomology, vol. 12, no. 3, pp. 982-985. http://dx.doi.org/10.1093/ee/12.3.982.

SHAPIRO, M., EL SALAMOUNY, S. and SHEPARD, B.M., 2008. Green tea extracts as ultraviolet protectants for the beet armyworm, Spodoptera exigua, nucleopolyhedrovirus. Biocontrol Science and Technology, vol. 18, no. 6, pp. 591-603. http://dx.doi. org/10.1080/09583150802133271.

SHOREY, H. and HALE, R.L., 1965. Mass rearing of the larvae of nine noctuid species on a simple artificial medium. Journal of Economic Entomology, vol. 58, no. 3, pp. 522-524. http://dx.doi. org $/ 10.1093 /$ jee $/ 58.3 .522$.

SINGH, N.P., VINOD, K. and DEEPAK, C., 2005. Baculoviruses: their use and limitations. Journal of Experimental Zoology India, vol. 8, no. 1, pp. 1-16.

YOUNG, S.Y. and YEARIAN, W.C., 1974. Persistence of of Heliothis NPV on foliage of cotton, soybean and tomato. Environmental Entomology, vol. 3, no. 2, pp. 253-255. http:// dx.doi.org/10.1093/ee/3.2.253.

ZARIN, I. and EGLITE, G., 1985. Antioxidants promising compounds for the protection of entomopathogenic viruses from UV rays. Trudy Latviiskoi Sel' skokhozyaistvennoi, vol. 222, pp. $15-21$. 